\title{
Missionary children: The French Holy Childhood Association in European context, 1843-c.1914
}

Article

Accepted Version

Heywood, S. (2015) Missionary children: The French Holy Childhood Association in European context, 1843-c.1914. European History Quarterly, 45 (3). pp. 446-466. ISSN 14617110 doi: https://doi.org/10.1177/0265691415585221 Available at https://centaur.reading.ac.uk/36785/

It is advisable to refer to the publisher's version if you intend to cite from the work. See Guidance on citing.

To link to this article DOI: http://dx.doi.org/10.1177/0265691415585221

Publisher: SAGE Publications

All outputs in CentAUR are protected by Intellectual Property Rights law, including copyright law. Copyright and IPR is retained by the creators or other copyright holders. Terms and conditions for use of this material are defined in the End User Agreement.

www.reading.ac.uk/centaur

\section{CentAUR}


Central Archive at the University of Reading

Reading's research outputs online 


\title{
Missionary children: The French Holy Childhood Association in European context, 1843-c.1914
}

\begin{abstract}
In the mid-nineteenth century, thousands of children in Europe and beyond were organized into battalions of fundraisers for overseas missions. By the end of the century these juvenile missionary organizations had become a global movement, generating millions of pounds in revenue each year. While the transnational nature of the children's missions and publications has been well-documented by historians, the focus has tended to be on the connections that were established by encounters between the young western donors, missionaries overseas and the non-western 'other' constructed by their work. A full exploration of the European political, social and cultural concerns that produced the juvenile missionaries movement and the transEuropean networks that sustained it are currently missing from historical accounts of the phenomenon. This article looks at the largest of these organizations, the Catholic mission for children, the French Holy Childhood Association (L'Euvre de la sainte enfance), to understand how the principles this mission sought to impose abroad were above all an expression of anxieties at home about the role of religion in the family, childhood and in civil society as western polities were modernizing and secularizing in the nineteenth century.
\end{abstract}

\section{Keywords}

Overseas missions, children, religious revival, Catholic internationalism, culture wars, secularization.

\section{Introduction}

As overseas missionary activities expanded during the religious revival of the nineteenth century, the new phenomenon of missionary societies for children developed. The idea that children had an important contribution to make to missionary movements originated in Europe in the early 1840s. It was pioneered by the Methodists and Baptists in Britain, swiftly followed in 1843 by the Catholic Holy Childhood Association ( $L$ 'Euvre de la sainte enfance) in France. ${ }^{1}$ Within a few years, thousands of children were organized into battalions of fundraisers across the continent and beyond. Children in Europe were told of the plight of children far away. Through the use of stories, songs or plays, they learned of their own privileged place in the world order, and the duties this entailed towards the less fortunate. These organizations, by attracting children with their message, fostered vocations for mission, trained new recruits for the adult home effort, and collected funds. Through their smaller 'child size' subscriptions (usually a penny, or sou or pfennig per month) the children's missions collected a significant proportion of the sums raised by the missionary movement overall: Prochaska estimates that English children's donations over the century 'added up to millions of pounds', 2 while according to Claude Prudhomme, the French Holy Childhood generated on average about one third of the 
income of the adult Association for the Propagation of the Faith, the other French Catholic mission. This reached up to four million francs per year at the end of the century. ${ }^{3}$ By this time, most of the overseas missionary organizations were developing publications specifically designed for children. ${ }^{4}$ In short, it had become a mass phenomenon across the large industrialized European countries, with operations reaching over the globe.

Why was there such an impressive mobilization of children for missions across Europe in the second half of the nineteenth century? How does this phenomenon fit into the story of the extra European expansion of organized religions? To begin to answer these questions, we must first situate these missions within the grand narratives of religious revival and the history of transnational organizations. At home, the children's missions followed the same pattern as religious revivalism in the postrevolutionary era more generally, in their mobilization of women and children through voluntary associations and schools, and their use of cheap religious periodicals and other forms of publishing that were expanding in the nineteenth century. ${ }^{5}$ With their global reach, the children's missions are also a significant example of what Abigail Green and Vincent Viaene have termed 'religious internationals'; the transnational voluntary religious organizations that came to the fore in the modern era. ${ }^{6}$ Green and Viaene argue that international history must take into account the role of religion in the development of civil society on a global scale, and how organized religions harnessed modern technologies in what Viaene calls 'a global effort to reform modern society in accordance with the church's principles'. The religious desire to reform society may have been global in ambition, but, as Viaene points out in the Catholic case, it was also a product of the social and political dislocations of the nineteenth century in Europe. The principles that the religious internationals sought to impose abroad were by no means stable and uncontested at home. Advances in communications and transport technologies, along with the rise of the modern nation state and secular ideologies threatened the position of religion in society; and many of these transformations affected children and the family in particular. ${ }^{8}$ The final element in our narrative of the children's missions - the history of childhood - must be written into the history of the religious internationals, to show how and why the young at home became important actors in the religious revivalism of the period.

Children's missions must be understood in the context of the emerging sentimental vision of childhood that historians agree emerged in the industrializing west in this period. ${ }^{9}$ Childhood was perceived to be a special stage in life, and consequently, the idea developed that it was qualitatively different to adulthood, and required particular treatment. Concurrently, the development of modern liberal polities, with their expansion of state administrative functions, saw governments intervening in areas traditionally governed by churches, notably education, marriage, sexuality and the family. ${ }^{10}$ Modern churches across Europe were also instrumental in both shaping and exploiting the new vision of the young. The nineteenth century witnessed the massive expansion of religious schools, the exaltation of mothers as 'priests in the home', and latterly, the creation of youth groups and the scouting movement. ${ }^{11}$ This led to increasingly bitter power struggles between churches and states. The conflicts were both cultural; the struggle was to define who could claim to be the protector of children; and political, as the church fought to counter the expansion of state and secular education. ${ }^{12}$ The implication of the children's missions in these challenges to 
churches and their role in civil society, and thus their growing importance to the religious revival, mean that it is essential to examine the distinctly European context that shaped missionary work with children both at home, and in the home. While the transnational nature of the children's missions and publications has been welldocumented by historians, the focus has tended to be on the connections that were established by encounters between the young western donors, missionaries overseas and the non-western 'other' constructed by their work. ${ }^{13}$ The importance of forging strong European links between members at home, in defiance of expanding nation states, has therefore been overlooked. A full exploration of the European political, social and cultural concerns that produced the juvenile missionaries movement and the trans-European networks that sustained it are currently missing from historical accounts of the phenomenon.

To investigate these aspects of the children's missions, this article uses the French Holy Childhood Association as a case study, because it was the largest transnational juvenile mission and it served as a model for many subsequent organizations. This is not to claim that all the findings on this Catholic mission can be applied universally, but parallels and differences with the Protestant missions will be highlighted. The Holy Childhood was established in Paris in 1843 by Mgr de Forbin-Janson (17851844). The mission's founding legend describes how concerned by stories sent home from missionaries in China of the allegedly widespread practices of infanticide and abandonment of children, the bishop decided that the plight of these children would also touch the hearts of children at home in France. His new mission asked children under the age of twelve to give a 'penny for the little Chinese' for their baptism, and to pray for their souls. Their donations supported a growing global network of orphanages, and often went towards buying or 'rescuing' young children from their impoverished parents in China. ${ }^{14}$ Within a decade, it had become a mass membership organization in the west, with 660,000 members in 1852 . It swiftly expanded its operations beyond French borders. Belgium and Canada joined the association the year it was established, followed in the late 1840s by Bavaria, Prussia and the AustroHungarian Empire. Donations were soon being sent to the central committee in Paris from across the globe, including countries such as Spain, England, Russia, Sweden, Chile, Brazil and Mexico. By the early 1850s regional councils were established in Aachen, Munich, Mainz and Vienna. Its main donors were located in the heartland of Catholic Europe in this era, namely France, Belgium, Austria, Italy, Prussia and Bavaria.

Given its scale, a truly transnational history of the Holy Childhood even within Europe is beyond the limits of this essay. Instead, I propose to follow the model many scholars of transnational history opt for, namely, to study one nation or institution based within a politically defined territory, but place its history in a wider, transnational context. ${ }^{15}$ To set the French Holy Childhood Association in its European context, this essay is divided into three parts. The first part explores how religious concerns to protect the family from state incursions shaped the new mission's strategies across Europe, and how it mobilized the structures of the religious revival at home. The second part traces the ways in which the Holy Childhood sought to integrate children into the new transnational European communities of opinion forged by the religious internationals. The final part looks at how by the late nineteenth century the mission's transnational and national identities came into conflict with one another in an age of high imperialism and nationalism. Throughout, the essay will 
investigate the dynamic and increasingly tense interplay between children, state, civil society and religious internationals that characterized the children's missionary movement.

\section{European revivalism: missionaries at home, missionaries in the home}

The Holy Childhood's success in moving across national boundaries stemmed from its astute approach to mobilization, in which it used the two groups who came to the fore in the associational and institutional life of the revivalist religion of the nineteenth century: women and children. Viaene points to the role of the large transnational congregations as 'key channels for cultural transfer' of both devotional practices and organizational models in the nineteenth century. ${ }^{16}$ The Holy Childhood both mobilized these channels, and acted as a vector for transferring a model of social activism which could be easily replicated in different national contexts. Crucially, in each member nation, the Holy Childhood sought to combat dechristianization and to compete with the state for influence over the family. It is this form of social activism that will now be discussed.

Historians often explain the phenomenal success of the juvenile missions by their appeal to mothers. As Prochaska wrote in his study of the British case: 'where women worked children were likely to follow. ${ }^{17}$ Likewise, Vincent Viaene and Henrietta Harrison both conclude that the Holy Childhood's fundraising activities were driven primarily by the energies of the children's mothers. ${ }^{18}$ As this section will set out, while it is true that women were important actors in the spread of the Holy Childhood, they were only one part of its mobilization strategy. There was certainly good reason for the mission to reach out to women, namely to harness the first great force of the nineteenth-century religious revival: the women who famously swelled the ranks of the faithful across Europe. ${ }^{19}$ By the mid-century the semi-official newspaper of the Vatican, the Civilità Cattolica, observed that in churches everywhere across Europe women outnumbered men. ${ }^{20}$ At the end of the century, over two-thirds of the half million religious counted in Europe were women. ${ }^{21}$ The Holy Childhood's fundraising strategies clearly sought to speak to this large audience. Children could become members of the Holy Childhood from baptism until their first communion (after which they became associate members), and so their mothers were all-important in enrolling their children and paying their subscriptions. Many donations were received from mothers for their unborn or deceased children (for whom there was celebrated an annual mass). The mission drew upon the new discourse of 'moral motherhood' developed in the post-revolutionary era, which underscored the pivotal role that women had to play within the family by exerting their moral influence over their children and husband, to save their church by bringing their families back to the fold. They were hailed as 'priests of the home'. ${ }^{22}$ Mothers were to inculcate devotion early, such as teaching children prayers and charity. The first issue of the Holy Childhood's Annales presented the mission as helping in this crucial task: 'mothers, profoundly moved [by the tales of infanticide] saw in this mission both the means by which they could replace these unnatural mothers, and assure celestial protection for their own young family by giving such well placed and deserving alms. ${ }^{23}$ Similarly, one of the early images the Holy Childhood distributed (c.1858), presented a mother holding up her young child so that he can place his penny into the collection box. ${ }^{24}$ 
In the context of a 'feminized' church, the use of imagery of abandoned and vulnerable children to tug on mothers' heartstrings was an obvious way of tapping a large income stream for the overseas missions. The mission used its child members to intensify the emotive appeal to their mothers. The children would dress in Chinese costume when asking for alms for the 'little Chinese'. While the Holy Childhood's publications and sermons might describe in awful detail the suffering of the Chinese babes, that was nothing compared to the pathos for mothers of seeing their own offspring act out such scenes. Watching their own children pleading not to abandon them no doubt recalled in mothers' minds the problem of unwanted children that was very real in Europe as well. Henrietta Harrison notes the 'extraordinarily high rates of abandonment' during the course of the eighteenth and nineteenth centuries in the major European cities. ${ }^{25}$ This unspoken parallel between the European and Chinese situations ensured the Holy Childhood made sense to European mothers, and was therefore easily translated into different national contexts.

By extension, the Holy Childhood perceived its young members as having a special role to play for their church at home - as the Director of the Holy Childhood put it in 1861: 'beloved children, allow us to say it, in these evil times, you are the hope of religion and society. ${ }^{26}$ The mission provides an excellent example of the ways in which the Catholic church exploited new ideas on childhood that were emerging in the industrializing west. As Viviana Zelizer has shown, modern childhood had become invested with an almost 'sacred' value, and in this context developed the idea that children might have a redemptive power in society. ${ }^{27}$ Indeed, the use of the young to reach out to their families in areas where the population might be indifferent or even hostile to the Catholic church became one of the features of missionary work in post-revolutionary era Europe. Children were perceived to be, in the words of the leading religious author and close ally of Pope Pius IX, Mgr de Ségur, 'little missionaries in the home'. He argued that by educating and helping children, the church would melt their parents' hearts, and lead to conversions. ${ }^{28}$ Rebecca Rogers has shown how girls in convent schools were encouraged through their charitable work in the community to see themselves as missionaries. ${ }^{29}$ Likewise, Mgr de ForbinJanson wrote of how important the young members of the Holy Childhood could be for inspiring not just generosity, but also religious sentiments. In a village on the outskirts of Paris, he wrote, the parents who had long ago deserted the church were 'pleased to see their children demonstrating their generosity of spirit and sensitivity to such heart-rending misery. ${ }^{30}$ The mission encouraged children to project themselves into the role of missionaries, to see themselves as active religious subjects. A recurrent image in the Holy Childhood's membership cards was of the little members of the mission by Forbin-Janson's side, taking the Chinese babes into their arms and protecting them from the pigs and wild beasts. Similarly, the ceremonies always held a raffle to close the festivities, in which children were given the prize of a Chinese baby being baptized with their name - a practice that Evelyn Waugh would famously satirize later, in Brideshead Revisited, when Cordelia Flyte explains the principle: 'you send five bob to some nuns in Africa and they christen a baby and name her after you. I've got six black Cordelias already. Isn't it lovely? ${ }^{31}$ Such interest in fostering children's spirituality was not, of course, original to the nineteenth century; however, it is fair to say that it intensified in the revivalist Catholicism of the nineteenth century, and produced new, child-centred forms of religious activism. 
Thus, without seeking to deny the mission's efforts to appeal to European mothers, we should be careful not to miss the point of the Holy Childhood and the other juvenile missions: they were designed for children. 'This mission is special', as the president of the Holy Childhood explained in 1850, 'because it is principally and almost exclusively a mission for children. Children are the objects of its charity; and children are placed at the head of the series and divisions which compose this charitable Association. ${ }^{32}$ A few years later, the treasurer in his report to the Holy Childhood's central committee emphasized the 'immense moral advantage' of its publications (on which, as will be discussed below, the mission spent a significant proportion of its income), and urged the directors to remember that the Holy Childhood had become an association 'for the Christian education of children, almost separate to the mission for the little Chinese. ${ }^{33}$ This double aim of the missions was encapsulated in the Holy Childhood's slogan: 'children saving children'. This mission must be understood as part of the immense work that was being carried out across post-revolutionary Europe to expand Catholic education - in the broadest sense of the word - amid ongoing concerns about the designs of the state on the young. The grand plans of the French Revolution to build a republican education system had led to the closure of Catholic schools, particularly in France and Belgium, while the dismantling of teaching congregations and the persecution of priests across revolutionary era Europe had severely hampered the provision of catechism classes. Education was subsequently felt by the left to be central to the continuation and completion of the revolutionary project while, correspondingly, the Catholic church saw it as bulwark against republicanism and one of the principal ways to restore the church to the heart of European society. ${ }^{34}$ One of the first aims of Mgr de Forbin-Janson was that the Holy Childhood work hand in hand with schools and support their work. ${ }^{35}$

It is therefore no surprise that the rapid development of the Holy Childhood Association between the 1840 s and the 1880 s coincided with the expansion of Catholic teaching congregations during the religious revival. ${ }^{36}$ The development of children's missions in Europe was closely linked to the growth of formal systems of education. Just as the British Protestant missions relied upon Sunday schools to fill their ranks, so the Catholic schooling sector provided a natural recruiting ground for the Holy Childhood. The bulk of the Holy Childhood's members were recruited from schools and other institutions that worked with children. The Brothers of the Christian Schools (Frères des écoles chrétiennes) were among the founding members of the Holy Childhood, and helped to spread the mission through their elementary schools for poor and working-class boys in France and Belgium. Jesuit schools were instrumental in promoting the mission amongst the social elite of Europe. The lists of donors published in the annual diocesan reports by the Association indicate that a wide range of Catholic schools and institutions became involved: seminary schools, convents, orphanages, and perseverance missions. ${ }^{37}$ Teachers enrolled their pupils, priests used catechism classes to preach about the mission in non-Catholic schools, and copies of the Annales were deposited in school libraries. In some cases a certain amount of pressure was exerted on pupils to join: one rulebook used by the Visitation convent school for girls in Paris indicates that all the pupils were required to apply to join the Holy Childhood Association, and if they misbehaved or broke the school rules they lost their membership. ${ }^{38}$ In contrast to the British Protestant missions, whose dependence on the Sunday Schools meant that most of their members were from working-class backgrounds, the participation of the teaching congregations and 
the different types of institutions ensured that the Holy Childhood Association recruited members from a broad social mix and both genders.

When the Holy Childhood was granted canonical status by Pius IX in 1856, it is striking that the accent in his papal brief was on role of the mission in modern European society, rather than its impact overseas. The Pope took especial delight in the fact that this mission was part of the great fight against secularization - 'this sterile philosophy' - and that its most valiant soldiers were 'children of the most tender age'. Such missions, he continued, would strengthen the unity of the Catholic Church, and he underlined the formative role the Holy Childhood played in this process, for it 'calls upon Catholic children and spurs them on to the efforts of which they are capable in order to save these poor little abandoned babes', and through such acts of charity they recognize the 'admirable light of the Faith' [italics in the original text]. ${ }^{39}$ The model of social activism that was so successfully exported by the Holy Childhood was shaped in the context of the transformations that were taking place in the family and its relationship to the state in post-revolutionary Europe. This was why the idea of 'children saving children' was so readily translated across Europe.

\section{Uniting Catholic children across Europe and the globe}

The Holy Childhood's mobilization of women and children was about much more than simply generating funds to send abroad; it was also an effective way of promoting the message that the Catholic church protected the family. This section looks at the new identities forged by the mission's propaganda work; at how the Holy Childhood promoted a positive pan-European identity through the notion of Catholic children working together for the 'little Chinese'. By extension, the Holy Childhood's desire to export the western model of childhood to the 'little Chinese' must be seen as part of the Catholic church's work to style itself as the guarantor of that privileged state at home.

In his brief on the Holy Childhood cited above, Pius IX highlighted the unifying role the missions could play in the Catholic church. As Cabanel remarks, such was the reach of the French overseas missions through their propaganda that tiny hamlets and little dioceses deep in the countryside were situated 'at the heart of these mass currents', linked through print and propaganda to a global movement. ${ }^{40}$ Still, while missions constructed a sense of global connectedness, at the core of their message was a powerful sense of common European endeavour. Judith Becker's study of Protestant missionaries in the 1830s underlines their emphasis on their European identity, which in some respects was 'more important to them than their own nation'. ${ }^{41}$ Christopher Clark has pointed to the role of the Catholic press in forging a 'partially Europeanized' public sphere in the second half of the nineteenth century. By reporting on events that affected Catholics across the continent, such newspapers encouraged readers to draw links between their experiences and those of their coreligionists in different countries. In this way, 'the Catholic papers helped to build that transnational community of sentiment that was so characteristic of European (and to a lesser extent, global) Catholicism in the last decades of the century'. ${ }^{42}$ Likewise, the Annales of the Holy Childhood Association explained to its young members that they were 'united with children across the Catholic world in working towards the same goal' ${ }^{43}$ Indeed, the case of the Holy Childhood demonstrates that thanks to the children's missions, with their active programme of festivities and activities designed 
to involve the young, in which this message could be expanded upon and reinforced, children were more readily connected than most.

The Annales de l'Euvre de la Sainte Enfance played the key role in developing connections between the small local communities that formed the basic units of the Holy Childhood and the wider transnational networks of the organization to which they belonged. Indeed, the Association's greatest expenditure was on producing its Annales, images and medals for propaganda purposes. In 1852, when its income from donations was just under one million francs per year, the annual expenses came to $78,169.67$ francs, of which approximately 68,000 francs were spent on the production and transport of printed materials and medals. ${ }^{44}$ The significant outlay they required was acknowledged to be a necessary part of the mission's work, almost equal to its missionary work overseas. The French edition of the Association's Annales after an initial print run of 15,000 in the 1840 s rose to 102,000 in 1860 , and 200,000 by $1900{ }^{45}$ The print runs for the translated editions fluctuated and were not always recorded so carefully, but central committee reports indicate that the print runs of all editions combined reached 315,000 by the 1850s. By 1897 editions of the Annales were being translated into English, German, Spanish, Italian, Flemish, Portuguese, Dutch, Hungarian, Czech, Maltese, Slav, Polish and Danish. As well as the printed word, the Holy Childhood distributed 440,000 images and 700,000 medals in 1860 alone, and by the twentieth century, this figure reached one million for both images and medals. ${ }^{46}$ Given its central role in uniting the mission, the production of such material, and particularly the Annales, was centralized, with the content controlled to reflect the concerns of the central committee. Thus, until the final decades of the century, national editions of the Annales were usually straightforward translations of the French editions; national councils had to go through the central committee in Paris if they wished to make suggestions for the Annales. ${ }^{47}$

The publication was divided into two sections. The first carried highly repetitious stories of abandonment and infanticide, detailed accounts of the rescue work carried out by the missionaries, and reports on the political situation and hardships the missionaries faced in these far-off lands. The missions sent back long letters explaining their work, describing their schools, and explaining what life was like in their country. Such letters aimed to inspire children with the tales of the selfless martyrdom of the men and women working out in these 'pagan' lands, and to encourage vocations for mission. Above all however, they forged a sense of belonging and identity amongst young members, using the Chinese children as the 'other'. The new respect for childhood, this 'privileged' state that was developing as an ideal in modern industrialized west, was presented as a particularly European value. In the Holy Childhood's hymn 'Listen, from deepest China' (Écoutez du fond de la Chine) the 'poor Chinese' babes emphasized how lucky their European benefactors were:

Listen, from deepest China

Thousands of orphans are crying out to you

Listen to their childish voices,

Tender brothers, help us!

Ah, how your mother is good

Such care she takes of you

But ours has abandoned us, 
The mission's propaganda material constantly reiterated this theme. Typical of the tone in the letters from missionaries published in the Annales is this missive from the Jesuit missionary, Father Leboucq, based in Tchao-Kia-Tchouang (Shijiazhuang): 'oh you little children, your cries are only ones of joy and happiness, in China, they are only of pain! [.... Ah yes, you are happy! You are the beloved brethren of the infant Jesus!' Even the poorest children in Europe are privileged, he continued, for they have loving mothers, and Leboucq invited them to compare their lives to the fate of Chinese babies, who, when they were not murdered, were unloved. ${ }^{48}$ This is a process described by Judith Becker in her study of Protestant missionary journals: 'by ascribing non-Christian vices to indigenous peoples and by underlining the assimilation of converts to Europeans, the missionary movement turned values which had been assumedly Christian into European Christian values. By emphasizing and repeating them in every issue of their journals, the societies helped to establish them as European Christian standards among their readers. ${ }^{49}$ When thinking about the Chinese 'other', the Holy Childhood forged a sense of common European identity, and sought to minimize the differences between the European member countries.

This material occupied just under half of the publication; the second section was devoted to describing the fetes, plays, processions and other fundraising efforts of its western members, as well as tabulating the donations the association had collected in each diocese, and each country. Whenever a parish organized a fete, the organizers would then send an account of the ceremony to the institute, which published it in the Annales. This was designed to bind the members across the different parishes, regions and countries together, and to encourage them to emulate one another. The Annales praised the young members, and rewarded them by giving them the pleasure of seeing their group appear in print. Over the course of the century, the descriptions of the fetes become increasingly elaborate, and by the twentieth century the texts were accompanied by pictures of the children in their costumes. Each issue of the Annales had a section entitled 'Review from abroad' which summarized the activities in each country. The donations from each member state were then tabulated, accompanied by encouraging commentary. Belgian children might be exhorted to maintain their country's excellent record, ${ }^{50}$ while an American pamphlet from 1861 noted that America arrived only seventh in the list of all the donor countries. ${ }^{51}$ The list at the end of each year would compare the best performing dioceses in the entire organization; members in Cambrai, Paris or Saint-Brieuc compared their efforts with children in Ghent, Montreal or Breslau. The space occupied by the accounts of such activities in the Annales is testimony to the significance the Association attached to fostering such friendly rivalry. And it was not simply the adult newspapers identified by Christopher Clark that encouraged Catholics to feel solidarity with their beleaguered coreligionists in other countries: under the laicizing reforms of the Third Republic, French children were exhorted to remember their German brothers had ten years previously undergone similar troubles during the Kulturkampf, but rather than faltering, donations from Germany had increased. In this way, the Holy Childhood sought to inspire its young members by the hard work and enthusiasm of their fellow Catholic children across the continent and beyond, and to feel a sense of fraternity with them. 
Just as the press sought to forge a sense of community and solidarity between adult believers across borders, so the Holy Childhood taught children of each other's plight, not just that of children in far-off lands, but also just beyond their national boundaries. Claude Prudhomme argues that the success of the largest Catholic overseas mission, the Propagation of the faith, when compared to other missions or colonial enterprises can be explained by its publication, the Annales de la Propagation de la Foi, which provided its members with a sense that as individuals they were engaged in a 'collective enterprise'. ${ }^{52}$ Likewise, this notion was central to the work of its sister organization, the Holy Childhood. Anderson notes that this collective identity had importance closer to home as well. The different elements of the religious revival worked together to forge the notion that Catholicism was more than a faith, it was also an identity that believers shared across boundaries of class, region or nation. This, she writes, gave revivalist Catholicism its political potential to mobilize believers. ${ }^{53}$

\section{Children, Catholic internationals and the nation-state}

The notion of 'children saving children' was therefore far from stable or unchanging. The Association's stories of 'other' childhoods overseas was to provide an important weapon in the ideological battle that the Catholic Church was fighting with expanding state machineries across its European heartlands. Henrietta Harrison has shown that the reality of the Association's work in China bore little resemblance to the straightforward situation of good and evil as painted in the Annales. ${ }^{54}$ Similarly, the children back home in Europe were the objects of increasingly bitter disputes between churches and states by the late nineteenth century. Perceptions of how the children in Europe could be 'saved' by the Association became more important, and differences in opinion between the member states on how this notion ought to be interpreted threatened to destabilize the unity of the mission as it expanded in the latter decades of the century.

The late nineteenth century proved turbulent for the Holy Childhood in Europe. By the 1890s it was generating millions of francs in donations per year. However, this success brought with it problems. National governments began to take more interest in its work, and the growth of its popularity in Germany and Austria threatened to shift the balance of power within the organization. Religious internationals, writes Viaene, 'transcended the borders of the nation state, but also presupposed it as the indispensable springboard for a supra-national identity and as the key module for concrete actions'. ${ }^{55}$ The Holy Childhood's ability to use national identities as the basis for its construction of a transnational community was the great strength of the mission, as described in the previous section, but it was also a potential source of division. At the same time as the Holy Childhood was growing, so the concert of Europe was looking increasingly fragile, and national rivalries were sharpening, particularly between France and a newly unified Germany, following the defeat the Prussians had inflicted on the French in 1870. Imperial expansion and the hostilities it led to between France and Germany further complicated the situation. Resentment grew within the member states towards what they perceived to be the 'French' bias of the mission.

The Association's relationship with expanding nation states was to experience difficulties in both France and Germany during the so-called 'culture wars', or intensification of the power struggles between churches and states at the end of the 
nineteenth century. ${ }^{56}$ Education was the site where churches and states clashed with the greatest force. Given its reliance on schools for recruitment and propaganda, and the militant ambitions it had to use them as a bulwark against secularization, the Holy Childhood was particularly vulnerable to this. In France, the Holy Childhood had hitherto had been ignored by the state, which had only been concerned by men's philanthropic organizations. ${ }^{57}$ While the government did not intervene in the work of the children's mission, problems began to emerge with the advent of the Third Republic in 1870, particularly once the anticlerical Republicans gained strength in the National Assembly by the end of the 1870 s. Reports from the dioceses increasingly referred to 'these troubled times' for the church in France. The Ferry reforms of the 1880 s banished religious symbols and imagery from state primary schools, and by the end of the century, all clerical personnel. Diocesan reports made reference to the difficulties they subsequently encountered. One branch in Brittany complained that the local government suppressed their processions and raffles and prevented them from diffusing the mission in communal schools (this region experienced particularly violent 'school wars'). ${ }^{58}$ Similarly, local authorities often tried to block religious processions, out of a suspicion of such public displays of grassroots power of the church. Such obstacles were a serious issue, for these processions, as we have seen, were central to the mission.

That said, the French experience of the so-called 'culture wars' in this period pales into insignificance in comparison with the German Kulturkampf of the 1870s, in which the state systematically repressed Catholic institutions and imprisoned or expelled thousands of clergy. ${ }^{59}$ Aside from the obvious consequence of incarceration that meant priests were unable to run the Association, the Holy Childhood was also gravely affected by reforms which banned Catholic priests and religious orders from schools. Nevertheless, just as the Kulturkampf proved a failure, so these restrictions did not check the Association's expansion. Indeed, the 1870s represented a period of expansion for the German branches. This was perhaps because its approach fitted well with the German Catholic response to state persecution, which was to create a Catholic subculture. By the 1890s, the mission was once more flourishing in German schools, although according to the secretary-treasurer of the Holy Childhood in Aachen, the fear that state repression could recur was strong. By his calculations in 1898, if the ban was renewed the Holy Childhood would lose if not half, at least a third of its income in Germany. ${ }^{60}$ The second great concern for the German members was the dislocation that German unification had caused to Catholic communities. The diaspora of German Catholic communities that had been created by migrations in the nineteenth century was now under a strong and aggressive Protestant government. This situation acted as a catalyst for the exacerbation of a long-standing disagreement within the Holy Childhood over its aims in Europe. Throughout the lifetime of the Association there had been regular calls for the mission to 'help' children at home, through the more active proselytizing of European children to save them from the threat of Protestantism and dechristianization. But the directors of the Holy Childhood had always remained steadfast in their refusal to divert funds to helping children in Europe, be they 'infidel' or no. ${ }^{61}$ Now there was a growing sense in Germany that the French directors were not showing sufficient understanding of their situation.

The national councils in Germany and Austria were becoming increasingly unhappy with the 'French' character of this supposedly international Association: its headquarters were in Paris, its central committee were all French, the business 
concerning the overall administration of the Association was conducted in French, the principal recipients of its funds were missionary orders that were French in origin, and French members donated by far the largest sums of money. The Viennese branch had long been trying to establish a separate, autonomous council as the clerical elite there wanted to have more say in the distribution of funds. From the 1850 s they submitted regular requests to the central committee asking if they could use some of the money for the baptism and education of Catholic children in Protestant regions, and these requests had been refused with equal regularity. However, the French direction came under increasing pressure to change its position. Annual reports to the central committee from 1890 onwards noted that the French contribution, hitherto the largest (approximately one million francs) was being overtaken by the Germans, and that the Belgian and Austrian branches were also going from strength to strength. It became clear that French donations were slowing due to a combination of factors: the loss of Alsace-Lorraine; stagnating birth rates; and the sluggish economy combined with an anticlerical government in France. In 1884, the Cardinal-Archbishop of Vienna announced his intention to amalgamate the three large fundraising missions in Austria into a body that would then be independent of the French organizations. ${ }^{62}$ The Pope was asked to arbitrate in the dispute but the resentment of French dominance in the German-speaking branches continued to grow. For Leon XIII it was clear: the statutes of the organization prevented it from working with children in Europe. Moreover, the Pope continued, if any city were to take over the direction of the mission, it would be Rome. He concluded that the Holy Childhood and the Propagation of the Faith were 'amongst the glories of France. We must not deprive her of this glory. ${ }^{63}$ Still, the directors were aware that the organization would have to change to reflect the new power dynamics, if France was to retain overall control. On the fiftieth anniversary of the Holy Childhood in 1893, the committee rewrote the statutes to include a stipulation that there must be foreign members in attendance at the annual general meeting of the Association.

The most serious threat to the unity of the Holy Childhood came from Germany. By 1895 the German donations had overtaken French contributions, at 1,110,281 francs and 1,091,068 francs respectively. The accompanying report in the committee minutes noted the German donations included Alsace Lorraine, as if to suggest that this might have tipped the balance, and the painful reminder of national humiliation this situation brought to the French members. ${ }^{64}$ The Germans began to complain vociferously about the unfairness of the distribution of the funds. In April 1895, the German edition of the Annales announced that henceforth children would be asked to give six pennies: five would go to the Holy Childhood, and one to a new mission whose role was to provide Catholic schooling for what the author called 'heathen' children in Germany. The article explained that in the vast areas of Germany where the Catholic diaspora lived, the fate of Catholic children also deserved pity for, living in Protestant communities, they grew up without instruction in their religion. A shortage of Catholic priests meant many did not take their first communion, and some were not even baptized. ${ }^{65}$ However this did not calm matters. At several points in the 1890s and early 1900s, the annual German Catholic Congress tabled motions to establish a separate, German-speaking Holy Childhood Association, although these efforts came to naught. This may have stemmed from a desire to strengthen connections between German-speaking Catholics, who had been disappointed by German unification without Catholic Austria. 
The tensions between France and Germany came to a head in the 1900s over imperial rivalries. Although the Holy Childhood had never acted in national imperial interests (on which it remained prudently silent) the tensions nevertheless threatened to erode the unity of the organization, because member countries saw their work in national terms. In August and September 1904, the Kölnischer Volkszeitung, a Catholic newspaper based in Cologne, printed a series of articles on how the Holy Childhood was using its funds. ${ }^{66}$ In the first article, the paper calculated from the published accounts that while Germans had donated 1,240,151 francs the previous year, the Holy Childhood had given only 35,000 francs to German missions (and that included Austrian missions). The newspaper concluded that this meant over one million francs of German money 'were being used to fund French missions', some of which, the article argued, were actively hostile towards German missions. Donors were in effect giving their money to a French organization that was providing subventions running counter to the German national interest. The Kölnischer Volkszeitung printed the Holy Childhood's response the following month, which argued that the Holy Childhood was an international organization, and above all, a Catholic organization, designed to aid Catholic missions, whose chief aim was 'to save souls'. The author also pointed out the difficulty in defining 'German missionaries' - should this be missionaries who trained in German schools? or missionaries who were themselves German? or simply those working in German imperial territories? The debate demonstrates the confusion that could arise from the increasing national tensions emerging within transnational organizations. The major congregations involved in mission work overseas were supposedly transnational, but in this case they were evidently considered (by the German members of the Holy Childhood but also by the central committee in Paris) to be linked to their native nation state.

The Kölnischer Volkszeitung articles of 1904 must be understood in the context of heightened tensions in Germany over French imperial ambitions. The entente cordiale with the English a few months earlier had emboldened the French in Morocco, and the following year this nearly led them into war with Germany. The problem, the third and final article in the Kölnischer Volkszeitung concluded, was that the popularity of the Holy Childhood had only achieved its zenith in Germany following the establishment of Catholic missions in German colonies. The author recounted how German missionaries had told him that 'zélateurs of the Holy Childhood sought to win over new recruits by suggesting to them that their subscription fees would go towards helping pagan children in German colonies'. Such expansion in support for missions encouraged by imperialism was characteristic of all missionary fundraising efforts. ${ }^{67}$ In spite of the emphasis in propaganda material on the importance of Catholic children working together, there was a growing gulf between the rhetoric and the grassroots work of the mission.

Ultimately however, the Holy Childhood emerged strengthened from these troubles. After the inevitable interruption brought about by World War One, the mission enjoyed a period of expansion and adaptation. ${ }^{68}$ The trends that were beginning to emerge in the $1900 \mathrm{~s}$ - increased autonomy for the national councils and greater sensitivity to the need to distribute funds more equitably across the different 'national' colonial territories and missions - became more pronounced and the mission took on more distinctive national characteristics in the member countries. The premise of 'children helping children' remained central to the appeal of the Holy Childhood, but it demonstrated more willingness to translate this concept for different member states. 
This had begun with the introduction of the combined mission in Germany in 1895 which called on children to donate both for missions overseas and for the "pagan children' at home. Similarly, the British branch began to grow and develop its own identity: the British Annals in the 1900s became much more vibrant and centred on activities in Britain, rather than simply translating the French edition. In the interwar period they changed the name of the Annals to the Swahili greeting Jambo! The accent was placed on work in Africa, so much so, that it became known popularly as the 'black babies collection'. The French mission aligned itself much more closely with the French imperial 'civilizing mission', participating in the colonial exhibitions, and showcasing its work with children in countries overseas. In Germany the economic dislocations of the 1920s initially proved dramatic, but subscriptions picked up quickly. The real saviour of the Holy Childhood lay across the Atlantic however, as donations from the United States increased massively. This followed the same pattern as the Protestant missions, which expanded into colonial and non-European contexts. $^{69}$

\section{Conclusion}

With its emphasis on emotive stories of moribund infants, the supposed ill treatment of children in far-off lands, and the redemptive power of young western children, the Holy Childhood mission chimed well with the new emotional investment in the child. It expanded swiftly within France, and was then translated and spread across the continent. Through its publications it developed and diffused an attractive identity of children working together across national boundaries that served to emphasize that the modern ideal childhood should be Catholic. The church and its young members would protect other children across the globe. However, as the organization grew over the course of the century differences arose within the large member states as to how the Holy Childhood ought to help children at home in Europe. The final decades of the century witnessed imperial expansion and clashes between nation-states which caused further serious divisions. These were resolved by the great cataclysm of World War One, which transformed the power balance within the organization. Ultimately, the French directors had to learn to adopt a more flexible approach that allowed for national approaches to children's mission work to develop in a more independent fashion.

Through studying the French Holy Childhood Association in its European context, this article has argued that the phenomenon of children's missionary societies was about much more than simply tapping a rich source of income, or even fostering the missionary spirit in the young - it was above all an expression of wider anxieties about the role of religion in the family, childhood and in civil society as western polities were modernizing and secularizing in the nineteenth century. As power structures were reconceptualized, social bonds were altered and reimagined. The Holy Childhood was one of the more successful examples of wider moves within churches to reclaim their role in societies through working with families, and how at home missions played as much of a role in competing with state and secular institutions to remain at the heart of civil society as they did in furthering their aims outside Europe. 
* Dr Sophie Heywood is lecturer in French Studies at the University of Reading. She specialises in the cultural and religious history of childhood in modern France. Her monograph Catholicism and Children's Literature in France: La comtesse de Ségur (17991874) was published by Manchester University Press (2011), and she has published articles on Catholic print culture in modern France and Jules Verne. She is currently working on a new book looking at publishing for children in France, 1945-75. S.1.heywood@reading.ac.uk

Author's note: I am grateful to the Pontificia Opus Sancta Infantia for allowing me to consult its archives and to its archivist Leonello Malvezzi for his guidance. I would like to thank Christopher Duggan, Joël Félix, Jack Harrington, and Colin and Olena Heywood for commenting on earlier drafts.

${ }^{1}$ On the juvenile missions in Britain, see Frank Prochaska, 'Little vessels: children in the nineteenth-century English missionary movement', The Journal of Imperial and Commonwealth History, 6 (1978), 103-118; Brian Stanley, 'Missionary Regiments for Immanuel's Service: Juvenile Missionary Organization in English Sunday Schools, 18411865', in Diana Wood (ed) The Church and Childhood, Studies in Church History 31 (Oxford, 1994), pp. 391-403. Felicity Jensz, 'Firewood, Fakirs and Flags: The Construction of the Non-Western "Other" in a Nineteenth-Century Transnational Children's Missionary Periodical', Schweizerischen Zeitschrift für Religions-und Kulturgeschichte, 105 (2011), 167191 studies the Moravian juvenile mission in Saxony, London and Philadelphia. On the French Catholic Holy Childhood Association, see Paul Lesourd, Histoire Générale de l'Euvre Pontificale de la Sainte-Enfance depuis un Siècle (Paris, 1947) and Un grand coeur missionaire: Monseigneur de Forbin-Janson 1785-1844, Fondateur de l'oeuvre de la saintenfance (Paris, 1944); Henrietta Harrison "A Penny for the Little Chinese": The French Holy Childhood Association in China, 1843-1951', The American Historical Review, 113 (2008) 72-92. On Protestant missions overseas in the colonial context of New Zealand, see Hugh Morrison, 'Little vessels' or 'little soldiers': New Zealand Protestant children, foreign missions, religious pedagogy and empire, c.1880s-1930s', Paedagogica Historica 47 (2011) 303-321.

${ }^{2}$ Prochaska, 'Little vessels', p. 104.

${ }^{3}$ Claude Prudhomme, 'L'argent des missions et les enjeux de pouvoir', in Michel Aubrun et al (eds) Entre idéal et réalité: Actes du colloque international d'histoire Finances et Religion (Clermont-Ferrand, 1994), pp. 367-88, p. 369.

${ }^{4}$ In Austria most of the missionary organizations produced materials for children, for example the St. Petrus Claver Sodality's Kleine-Afrika Bibliothek, and later Das Negerkind, while many missionary journals also contained special inserts for children. I would like to thank Katherina Stornig for her guidance on this. From the 1880s the French Propagation de la foi expanded into children's publications, J. P. Daughton, An Empire Divided: Religion, Republicanism and the Making of French Colonialism, 1880-1914 (Oxford, 2006), pp. 230-2. The Moravian church produced children's missionary publications, Jensz, 'Firewood, Fakirs and Flags'; for examples of British and Belgian publications, Jan De Maeyer et al, (eds), Religion, Children's Literature and Modernity in Western Europe 1750-2000 (Leuven, 2005). ${ }^{5}$ C.A. Bayly, The Birth of the Modern World 1780-1914: Global Connections and Comparisons (Oxford, 2004), chapter 9; Sheridan Gilley and Brian Stanley, (eds) The Cambridge History of Christianity, Volume 8: World Christianities c. 1815-1914 (Cambridge, 2006).

${ }^{6}$ Vincent Viaene, 'International History, Religious History, Catholic History: Perspectives for Cross-Fertilization (1830-1914)', European History Quarterly 38 (2008) 578-607; Abigail Green and Vincent Viaene (eds) Religious Internationals in the Modern World: Globalization and Faith Communities since 1750, (Basingstoke, 2012).

${ }^{7}$ Vincent Viaene, 'Nineteenth-Century Catholic Internationalism and its Predecessors', in Green and Viaene (eds) Religious Internationals, chapter 4, p. 84. 
${ }^{8}$ Christopher Clark and Wolfram Kaiser (eds) Culture Wars. Secular-Catholic Conflict in Nineteenth-Century Europe, (Cambridge, 2003). See also footnote 11.

${ }^{9}$ For a survey of the historiography since Philippe Ariès' path-breaking 1960 thesis, L'Enfant et la vie familiale, see Paula Fass, 'Is there a story in the history of childhood?', in Paula Fass (ed) The Routledge History of Childhood in the Western World (Abingdon, 2013), pp. 1-14; also Hugh Cunningham, Children and Childhood in Western Society since 1500 (Harlow, 2005), pp. 41-80; Colin Heywood, A History of Childhood. Children and Childhood in the West from Medieval to Modern Times (Oxford, 2001), pp. 23-31.

${ }^{10}$ James Schmidt, 'Children and the State', in Fass (ed) The Routledge History of Childhood, pp. 174-190.

${ }^{11}$ For a comparison of the Catholic and Methodist revivals, Margaret Lavinia Anderson, 'The Divisions of the Pope: the Catholic Revival and the Transition to Democracy', in Austen Ivereigh (ed.) The Politics of Religion in an Age of Revival (London, 2000), pp 22-42, pp. 2930; on child visionaries in post-revolutionary Europe, David Blackbourn, The Marpingen Visions: Rationalism, Religion and the Rise of Modern Germany (London, 1995), pp. 17-57; Gibson and Conway note the heightened interest in children's piety, Ralph Gibson, A Social History of French Catholicism 1789-1914 (London, 1989), pp. 190-2, 265-7; Martin Conway, Catholic Politics in Europe, 1918-1945 (London and New York, 1997), p. 14. On changing notions of children's saintliness, Anna Benvenuti Papi and Elena Gianarelli (eds) Bambini Santi: Rappresentazioni dell'Infanzia e Modelli Agiografici (Turin, 1991), pp. 7-24.

${ }^{12}$ Anderson, 'Divisions of the Pope', pp. 29-30; Jan De Maeyer 'The Concept of Religious Modernisation', in De Maeyer et al, Religion, Children's Literature and Modernity, pp. 41-50, p. 48.

${ }^{13}$ Harrison, 'Holy Childhood'; Jensz, 'Firewood, Fakirs and Flags'; Morrison, 'Little vessels' or 'little soldiers'.

${ }^{14}$ On just how wide the gap could be between the rhetoric of the mission's propaganda and the grim realities of the orphanages, see Harrison, 'Holy Childhood'.

${ }^{15}$ For further discussion of approaches to transnational history, see C.A. Bayly et al, 'AHR Conversation: On Transnational History', American Historical Review, 111 (2006),

111:1441-1464.

${ }^{16}$ Viaene, 'Catholic Internationalism', p. 91.

${ }^{17}$ Prochaska, 'Little vessels', pp. 103-4.

${ }^{18}$ Viaene, 'Catholic Internationalism', p.93; Harrison, Holy Childhood, pp. 76-9.

${ }^{19}$ On the 'feminization' of the Catholic Church, the foundational text is Claude Langlois, Le Catholicisme au féminin: Les congrégations françaises à supérieure générale au XIXe siècle (Paris, 1984); on Europe, Michela De Giorgio, 'La bonne catholique', in Georges Duby and Michelle Perrot (eds) Histoire des femmes en Occident, (Paris, 1991), volume 4:169-194.

${ }^{20}$ Quoted in De Giorgio, 'La bonne catholique', p. 172.

${ }^{21}$ Viaene, 'Catholic Internationalism', p.92.

${ }^{22}$ Hazel Mills 'Negotiating the Divide: Women, Philanthropy and the 'Public Sphere' in Nineteenth-Century France', in Frank Tallet and Nicholas Atkin (eds) Religion, Society and Politics in France since 1789 (London, 1991), pp. 29-54; De Giorgio, 'La bonne catholique', pp. 186, 196.

${ }^{23}$ Annales, January 1846. All translations are my own unless indicated otherwise.

${ }^{24}$ A collection of the memberships cards is held at the Archives de l'Archevêché de Paris, dossier 4K1.

${ }^{25}$ Harrison, 'Holy Childhood', pp. 77-79.

${ }^{26}$ Letter from the Director of the Holy Childhood to its members, reproduced in The Society of the Holy Childhood, American, c.1861, p. 35, British Library, General Reference Collection Mic.F.232.

${ }^{27}$ Viviana Zelizer, Pricing the priceless child: the changing social value of children (Princeton, 1994). 
${ }^{28} \mathrm{Mgr}$ de Ségur, La sanctification des enfants, second in a series of six articles in Bulletin de l'Association Saint François de Sales, February 1867. Ségur led the Holy Childhood's branch in Rome, while he was auditor of the rote in the 1850s.

${ }^{29}$ Rebecca Rogers, From the salon to the schoolroom: Educating Bourgeois Girls in Nineteenth Century France (Pennsylvania, 2005), pp. 157-8.

${ }^{30}$ Lesourd, Forbin-Janson, p. 265.

${ }^{31}$ Evelyn Waugh, Brideshead Revisited [1945] (London, 2000), p. 84.

${ }^{32}$ Mgr Parisis (President), Circular letter, 7 June 1850, Manuel de l'œuvre de la sainteenfance. Paris: Aux bureaux du Conseil Central, Edition de 1866, pp. 83-4.

${ }^{33}$ POSI, Procès-Verbaux B14, 7 June 1852.

${ }^{34}$ Gérard Cholvy, Mouvements de jeunesse. Chrétiens et juifs: Sociabilité juvénile dans un cadre européen (Paris, 2008).

${ }^{35}$ Lesourd, Forbin-Janson, pp. 190-1.

${ }^{36}$ Viaene, 'Catholic Internationalism', pp. 90-2.

${ }^{37} \mathrm{~A}$ collection of this material for French dioceses is preserved in the Bibliothèque Nationale de France [BnF], shelfmark 4-WZ-9383, Euvre pontificale de la Sainte-Enfance - Recueil documents d'information. See also the POSI folders for the individual donor countries, for example, letter to the Conseil central, Aix-la-Chapelle March 1898, POSI folder E2 (1) Allemagne, on the importance of schools in Germany.

${ }^{38}$ Règlement de l'Association de la Sainte-Enfance établie au pensionnat du premier monastère de la Visitation de Sainte-Marie de Paris. Paris: Au Monastère de la Visitation, 1893.

${ }^{39}$ See the papal brief dated 18 July, reproduced in the Annales, October 1856, pp. 337-51. The delay in endorsing the Holy Childhood was due to concerns that it posed a threat to the already established Propagation of the Faith.

${ }^{40}$ Patrick Cabanel, 'L'inculcation missionnaire dans les chrétienetés rurales: l'invention d'un imaginaire', in Chantal Paisant (ed), La mission en textes et images XVIe-XXe siècles (Paris, 2004), pp. 233-51, pp. 233, 235 and 246.

${ }^{41}$ Judith Becker, 'What was European about Christianity? Early 19th century missionaries' perceptions', in Brian Stanley (ed), Europe as the Other. External Perspectives on European Christianity. Veröffentlichungen des Instituts für Europäische Geschichte. Beihefte 103, (Göttingen, 2014), pp. 29-52, p. 29.

${ }^{42}$ Christopher Clark, 'The New Catholicism and the European culture wars', in Clark and Kaiser (eds) Culture Wars, pp. 11-46, p. 35.

${ }^{43}$ Annales February 1861, p. 47.

${ }^{44}$ POSI, Procès-Verbaux B14, 7 June 1852.

${ }^{45}$ Information on print runs and translations of the Annales was printed in the annual reports in the Annales, Lesourd's Sainte-enfance pp. 106-9, 143 is also helpful, and this data can be cross-referenced in the POSI, Procès-Verbaux B14-16.

${ }^{46}$ Lesourd, Sainte-Enfance, p. 143.

${ }^{47}$ For example: letter to the Conseil Central, 17 March 1877, POSI folder E2 (1) Allemagne.

${ }^{48}$ Annales, April 1861, pp. 92-3.

${ }^{49}$ Becker, 'What was European about Christianity?', p. 47.

${ }^{50}$ Annales, February 1857, p. 46.

${ }^{51}$ The Society of the Holy Childhood, American, c.1861, British Library, General Reference Collection Mic.F.232. p. 6.

${ }^{52}$ Claude Prudhomme, 'Quand triomphe la mission: autopsie d'un success', in Claude Prudhomme (ed) Une appropriation du monde: Mission et missions XIXème-XXème siècles (Paris, 2004), pp. 5-15, p. 11.

${ }_{53}^{53}$ Anderson, 'Divisions of the Pope', pp. 33-4.

${ }^{54}$ Harrison, 'Holy Childhood'.

${ }^{55}$ Viaene, 'International History, Religious History, Catholic History', p. 596.

${ }^{56}$ Clark and Kaiser (eds) Culture Wars. 
${ }^{57}$ Lesourd, Sainte-Enfance, pp. 33-4; the file in the Archives Nationales, $\mathrm{F}^{19} 6427$, indicates that the French government only began to carry out surveillance of the mission in the 1900s.

${ }^{58}$ Compte rendu, Brieuc and Treguiers, 1888-9, BnF, 4-WZ-9383, p. 8. On the 'school wars', see James F. McMillan, 'Priest hits girl': on the front line in the war of the two Frances', in Clark and Kaiser (eds), Culture Wars, pp. 77-101.

${ }^{59}$ For an overview and bibliography see Michael B. Gross, The War against Catholicism: Liberalism and the Anti-Catholic Imagination in Nineteenth-Century Germany (Ann Arbor, 2004).

${ }^{60}$ Letter to the Conseil central, Aix-la-Chapelle March 1898, POSI folder E2 (1) Allemagne.

${ }^{61}$ For some examples see: POSI, Procès-Verbaux B14, 26 January and 16 June 1853, 22 June 1854, Procès-Verbaux B16, 25 August 1882.

${ }^{62}$ POSI, Procès-Verbaux B16, 21 August 1884.

${ }^{63}$ POSI, Procès-Verbaux B16, 27 January 1892.

${ }^{64}$ POSI, Procès-Verbaux B16, 18 December 1895.

${ }^{65}$ Annales, German edition, April 1895, translation in POSI, E2 (1) Allemagne.

66 'Missions', Kölnischer Volkszeitung, August-September 1904, translations in POSI, E2 (1) Allemagne.

${ }^{67}$ Norman Etherington, 'Afterword: The missionary experience in British and French empires', in Owen White and J.P. Daughton (eds) In God's Empire: French Missionaries and the Modern World (Oxford, 2012), pp. 279-302, p. 284.

${ }^{68}$ See the graph of donations to the Holy Childhood, 1880-1924, POSI, E2 (1) Allemagne.

${ }^{69}$ Morrison, 'Little vessels' or 'little soldiers'. 